\title{
In vitro screening of different Pseudomonas fluorescens isolates to study lytic enzyme production and growth inhibition during antagonism of Fusarium oxysporum f. sp. cumini, wilt causing pathogen of cumin
}

\author{
Ridhdhi Rathore ${ }^{1,2}$, Dinesh N. Vakharia ${ }^{1}$ and Dheeraj Singh Rathore ${ }^{1,2^{*}}$ (D)
}

\begin{abstract}
Land plants exist in close association with bacterial and fungal microbes, where some associations can be pathogenic and others can be mutualistic/beneficial. One such relation exists between host plant, Cuminum cyminum L. (Cumin) and Fusarium oxysporum f. sp. cumini (Foc), the causal pathogen of cumin wilt and Pseudomonas fluorescens (Pf), where Pf acts as a bio-agent for inhibiting Foc and promoting plant growth of cumin. In this study, antagonism by 10 different $P f$ isolates against Foc was studied under laboratory conditions through percent growth inhibition and biochemical mechanisms. Among these Pf isolates, Pf-5 exhibited the highest in vitro growth inhibition (82.51\%). A positive correlation was observed between percent growth inhibition and specific activities of hydrolytic enzymes, chitinase, $\beta-1,3$ glucanase, and protease, where a negative correlation was observed with cell wall degrading enzymes, cellulase and polygalacturonase. To conclude, isolate Pf-5 could be a potential biocontrol agent for Fusarium wilt disease of cumin.
\end{abstract}

Keywords: Growth inhibition, Cumin wilt, Lytic enzymes, Microbe-microbe interaction, Pseudomonas, Fusarium

\section{Background}

Cumin (Cuminum cyminum L.) is widely grown as an important spice crop in arid and semi-arid regions of the Indian subcontinent. India is the world's largest producer, consumer, and exporter of cumin (Bhatnagar et al., 2013). The fungal disease wilt, caused by the soil-borne phytopathogens, Fusarium oxysporum f. sp. cumini $(F o c)$, is one of the major threats to cumin production in India and worldwide (Özer and Bayraktar, 2015).

For proper management of Fusarium wilt, an integrated approach combining cultural, biological, and

\footnotetext{
* Correspondence: dheeraj.rathore@teagasc.ie

'Department of Biochemistry, College of Agriculture, Junagadh Agricultural University, Junagadh, India

${ }^{2}$ Present address: Crop Science Department, Teagasc, Oak Park, Carlow, Ireland
}

Springer Open

(C) The Author(s). 2020 Open Access This article is licensed under a Creative Commons Attribution 4.0 International License, which permits use, sharing, adaptation, distribution and reproduction in any medium or format, as long as you give appropriate credit to the original author(s) and the source, provide a link to the Creative Commons licence, and indicate if changes were made. The images or other third party material in this article are included in the article's Creative Commons licence, unless indicated otherwise in a credit line to the material. If material is not included in the article's Creative Commons licence and your intended use is not permitted by statutory regulation or exceeds the permitted use, you will need to obtain permission directly from the copyright holder. To view a copy of this licence, visit http://creativecommons.org/licenses/by/4.0/.

chemical means is recommended to include the use of resistant cultivars and healthy seeds, adjustment of sowing dates, crop rotation, seed treatment, fungicide application, and biocontrol agents. However, several factors influence the efficacy of these management practices, including pathogenic variability in the fungal populations as well as abiotic factors such as agro-climatic conditions (Lodha and Mawar, 2014). More specifically, management of cumin wilt disease is difficult due to limited resistance against wilt in existing germplasm throughout the world (Lodha and Mawar, 2014). Due to the soilborne nature of Fusarium, the cultural practice of crop rotation restricts cumin cultivation for long periods as fungal spores can survive in soil for up to 6 years even in the absence of the host plant (Israel et al., 2005). Additionally, fungicides and organic compounds are widely 
used to control the wilt disease. Nevertheless, application of fungicides can have negative effects on crop physiology, especially on photosynthesis and pose a serious environmental threat (Petit et al., 2012).

Biological control of soil-borne diseases has been widely reported for successful crop production utilizing eco-friendly methods for several crops (Raymaekers et al., 2020). Biological control of plant diseases using antagonistic microorganisms offers a highly effective, economic, and environmentally friendly alternative to the use of synthetic pesticides (Iftikhar et al., 2020). Fungal agents such as Trichoderma spp. are continuously used by cumin growers to effectively control wilt disease (Lodha and Mawar, 2014). Three bacterial species, viz., Pseudomonas fluorescens (Pf), Bacillus subtilis, and Rhizobium spp., were also tested for their ability to control wilt disease. Recently, Chawla et al. (2012) studied the antagonistic potential of 4 pathogens as a biological agent, viz., Trichoderma harzianum, T. viride, P. fluorescens, and B. subtilis, against cumin wilt pathogen Foc under laboratory conditions. Interestingly, significant growth inhibition was observed by all the 4 pathogens, while maximum mycelial inhibition was recorded in the presence of Pf (Chawla et al., 2012). From previous reports, it is evident that lytic enzymes such as chitinase, $\beta-1,3$ glucanase, and protease are associated with the ability of Pseudomonas sp. to control plant pathogens (Bishi and Vakharia, 2015). However, the biochemical mode of action through which $P f$ antagonistically inhibits the mycelial growth, particularly for Foc, is still unknown.

Therefore, the present study aimed to evaluate the antagonistic potential of $10 \mathrm{Pf}$ isolates against Foc. Moreover, biochemical insight into microbe-microbe interactions of these new $P f$ isolates during antagonism with $F o c$ was implemented.

\section{Materials and methods}

\section{Isolation and maintenance of microbes}

Infected cumin seedlings that exhibit clear wilt symptoms were selected from a field experiment to isolate the fungal pathogen $F$. oxysporum f. sp. cumini (Foc). The infected tissues were cut into small pieces by using the flame-sterilized scalpel blade and were transferred to sterile Petri dishes containing 0.1\% mercuric chloride solution for the surface sterilization of plant tissues. Sterilized plant tissues were transferred to Potato-Dextrose Agar (PDA) plates and incubated for $96 \mathrm{~h}$ at $28 \pm 2{ }^{\circ} \mathrm{C}$ in an incubator to obtain full growth of the fungi. The resulted fungus was purified, using the hyphal tips technique on PDA medium. Further, pure culture slants of the fungus on PDA were prepared for future studies. The fungal pathogen was identified based on the colony characteristics and spore morphology as described by Booth (1971).

Ten isolates of P. fluorescens (Pf1-10) were obtained from the culture collection of the Department of Biochemistry, College of Agriculture, Junagadh Agricultural University, Junagadh, Gujarat, India. These bacterial strains were previously isolated from the cumin growing regions of Saurashtra, Gujarat, India. All the bacterial isolates were maintained by periodic transfers on King's $B$ medium under aseptic conditions to keep the cultures fresh and viable during this entire study.

\section{In vitro inhibition of $F$. oxysporum f. sp. cumini by $P$. fluorescens}

The in vitro antagonistic effect of the 10 isolates of $P f$ against the fungal pathogen $F o c$ was assessed by allowing both organisms to grow on dual culture media, King's B + PDA (1:1) in the Petri dishes. Pure and fresh cultures of $P f$ and $F o c$ were obtained by culturing in King's B for $72 \mathrm{~h}$ and PDA for 4-5 days, respectively. For the antagonistic study, a mycelial disc of $4 \mathrm{~mm}$ diameter agar plug containing Foc hyphae was placed in the center of a Petri dish containing dual media under aseptic conditions; each isolate of $P f$ was streaked in circular form maintaining $3 \mathrm{~cm}$ distance from the test fungal plug (Kandoliya and Vakharia, 2013). The Petri dishes containing only the test fungus $F o c$ were considered as the control. The Petri dishes were incubated at $28 \pm 2{ }^{\circ} \mathrm{C}$ for 6 days, and the observations were recorded. The experiment was replicated 3 times. Percent growth inhibition of Foc by Pf was calculated, following the method described by Fatima et al. (2009) as below:

\%Growth inhibition $=\{(C-T) / C\} \times 100$

where $\mathrm{C}=$ colony diameter of fungal pathogen $F o c$ in control Petri dishes $(\mathrm{cm})$, and $\mathrm{T}=$ colony diameter of $F o c$ in the inhibition Petri dishes $(\mathrm{cm})$.

\section{Extraction of lytic enzymes}

Crude enzyme extract was prepared from the Petri dishes containing Foc and $P f$ isolates (T1 to T10), and only the test fungus (T11) as a control at 6 days after inoculation (DAI). To perform, $25 \mathrm{ml}$ of $100 \mathrm{mM}$ phosphate buffer ( $\mathrm{pH}$ 5.5) containing $50 \mathrm{mM}$ sodium chloride was added to each Petri dish, followed by transferring the mycelia mat and the bacterial growth to prelabelled conical flasks. For enzymatic reaction, $1 \%$ of each of the following: carboxy methyl cellulose (CMC), sodium polypectate, chitin, laminarin, or casein were added into a flask containing culture, and the $\mathrm{pH}$ was adjusted to 5.5 (Kishore et al., 2006). Conical flasks containing the culture, buffer mixtures, were then incubated at $120 \mathrm{rpm}$ and $28{ }^{\circ} \mathrm{C}$ for $6 \mathrm{~h}$ in an orbital shaker (Sivan 
and Chet, 1989). Later, the content was transferred to pre-labelled 50-ml Falcon tubes and centrifuged at 14, $000 \mathrm{rpm}$ for $10 \mathrm{~min}$. Supernatant was collected and stored at $-20{ }^{\circ} \mathrm{C}$ for downstream assays such as enzymatic activity quantification.

\section{Cell wall degrading enzymes \\ Cellulase activity assay}

To perform this reaction, $100 \mu \mathrm{l}$ aliquot of the culture supernatant was mixed with $400 \mu \mathrm{l}$ of $100 \mathrm{mM}$ sodium citrate buffer ( $\mathrm{pH}$ 5.2) containing $1 \% \mathrm{CMC}$ and incubated at $55{ }^{\circ} \mathrm{C}$ for $15 \mathrm{~min}$. After incubation, the released glucose was measured using the Nelson Somyogi method (Sadasivam and Manickam, 1992). The specific cellulase activity was recorded as unit.mg ${ }^{-1}$ protein, where one unit of cellulase activity was defined as the amount of cellulase required to produce $1 \mathrm{mg}$ free glucose per minute per milliliter of enzyme extract.

\section{Polygalacturonase (PG) activity assay}

This assay was performed by mixing $100 \mu \mathrm{l}$ aliquot of the culture supernatant with $400 \mu \mathrm{l}$ of $50 \mathrm{mM}$ sodium acetate buffer ( $\mathrm{pH} 5.2$ ) containing $0.25 \%$ sodium polypectate and incubating the mixture at $37{ }^{\circ} \mathrm{C}$ for $60 \mathrm{~min}$. The released galacturonic acid was measured after the incubation period following the Nelson Somyogi method (Sadasivam and Manickam, 1992). One unit of polygalacturonase was defined as the amount of polygalacturonase required to produce $1 \mathrm{mg}$ free glucose per minute per milliliter of enzyme extract for which the specific activity is expressed as unit.mg ${ }^{-1}$ protein.

\section{Pathogenesis-related enzymes Protease activity assay}

The reaction mixture contained $100 \mu \mathrm{l}$ culture supernatant, $500 \mu \mathrm{l}$ of $0.36 \%$ bovine serum albumin, and $2 \mathrm{ml}$ of $100 \mathrm{mM}$ acetate buffer $(\mathrm{pH}$ 3.6). Reaction mixtures were incubated for $60 \mathrm{~min}$ at $50{ }^{\circ} \mathrm{C}$, and the reaction was stopped using $3 \mathrm{ml}$ of $5 \%$ trichloroacetic acid (Malik and Singh, 1980). The blank was treated as zero time incubation. The reaction mixtures were then centrifuged at $5000 \mathrm{rpm}$ for $10 \mathrm{~min}$ to settle the precipitate. A known volume of supernatant $(100 \mu \mathrm{l})$ was used for the estimation of released free amino acids using the ninhydrin method (Lee and Takahashi, 1966). The specific activity of protease was expressed as unit.mg ${ }^{-1}$ protein, and one unit of protease activity was defined as the amount of protein necessary to produce microgram free amino acids per minute per milliliter of culture supernatant.

\section{Chitinase activity assay}

This reaction mixture contained $200 \mu \mathrm{l}$ of $0.5 \%$ chitin in $10 \mathrm{mM}$ sodium acetate buffer $(\mathrm{pH} 5.2)$ and $100 \mu \mathrm{l}$ of culture supernatant, which was incubated at $50{ }^{\circ} \mathrm{C}$ for $60 \mathrm{~min}$. The formation of sugar $\mathrm{N}$-acetylglucosamine was measured using the dimethylamino benzaldehyde (DMAB) method (Reissig et al., 1955). The chitinase activity was recorded as micromole of GlcNAc (monomeric unit of the polymer chitin) released per milliliter per minute. The specific activity was expressed as units of enzymes per milligram of protein in the extract.

\section{$\beta-1,3$ glucanase activity assay}

The reaction contained $100 \mu \mathrm{l}$ of $4 \%$ laminarin in $50 \mathrm{mM}$ sodium acetate buffer (pH 5.2) and $100 \mu$ l of culture supernatant. The reaction mixtures were incubated at $37{ }^{\circ} \mathrm{C}$ for $10 \mathrm{~min}$. Post incubation, the glucose released by enzyme $\beta-1,3$ glucanase was measured according to the Nelson Somyogi method (Sadasivam and Manickam, 1992). The specific activity of the $\beta-1,3$ glucanase was expressed as unit.mg ${ }^{-1}$ protein. The unit activity was defined as the amount of enzyme necessary to produce $1 \mu \mathrm{M}$ of corresponding reducing sugar per minute per milliliter of culture supernatant.

\section{Statistical analysis}

All experiments were conducted in triplicate with a minimum of 3 technical replicates. The data were analyzed using the analysis of variance (one-way ANOVA) and using GenStat 14th Edition. Post hoc Tukey test was performed to analyze the significance among the treatments. Further, the correlation among different traits was studied using the PAST v1.89 software.

\section{Results and discussion}

\section{In vitro percent growth inhibition of Foc}

The efficiency of $P$. fluorescens isolates $P f 1-10$ on inhibiting the growth of Foc on dual media in Petri dishes is illustrated in Fig. 1, while the percent growth inhibition of $F o c$ during the in vitro interaction with bio-agent $P$. fluorescens isolates $P f 1-10$ at 6 DAI is shown in Fig. 2. Percent growth inhibition of fungal pathogen $F o c$ was recorded the highest (82.51\%) for $P f-5$ isolate in treatment $\mathrm{T} 5$, followed by T4, T3, and T2 with $74.91,69.12$, and $66.47 \%$, respectively, at 6 DAI. On the other hand, the inhibition growth percent for $\mathrm{T} 1$ and $\mathrm{T} 6-10$ treatments remained below 60\% (Figs. 1 and 2). Thus, antagonism study showed that isolate Pf-5 was the most efficient among the 10 isolates of $P$. fluorescens with a maximum growth inhibition (Fig. 2). This illustrates that the interaction between fungal pathogen $F o c$ and bio-agent $P f-5$ isolate was significant than other $P f$ isolates tested in this study. A previous study to suppress the Foc growth by integration of organic amendments (farm yard manure, vermicompost, and 

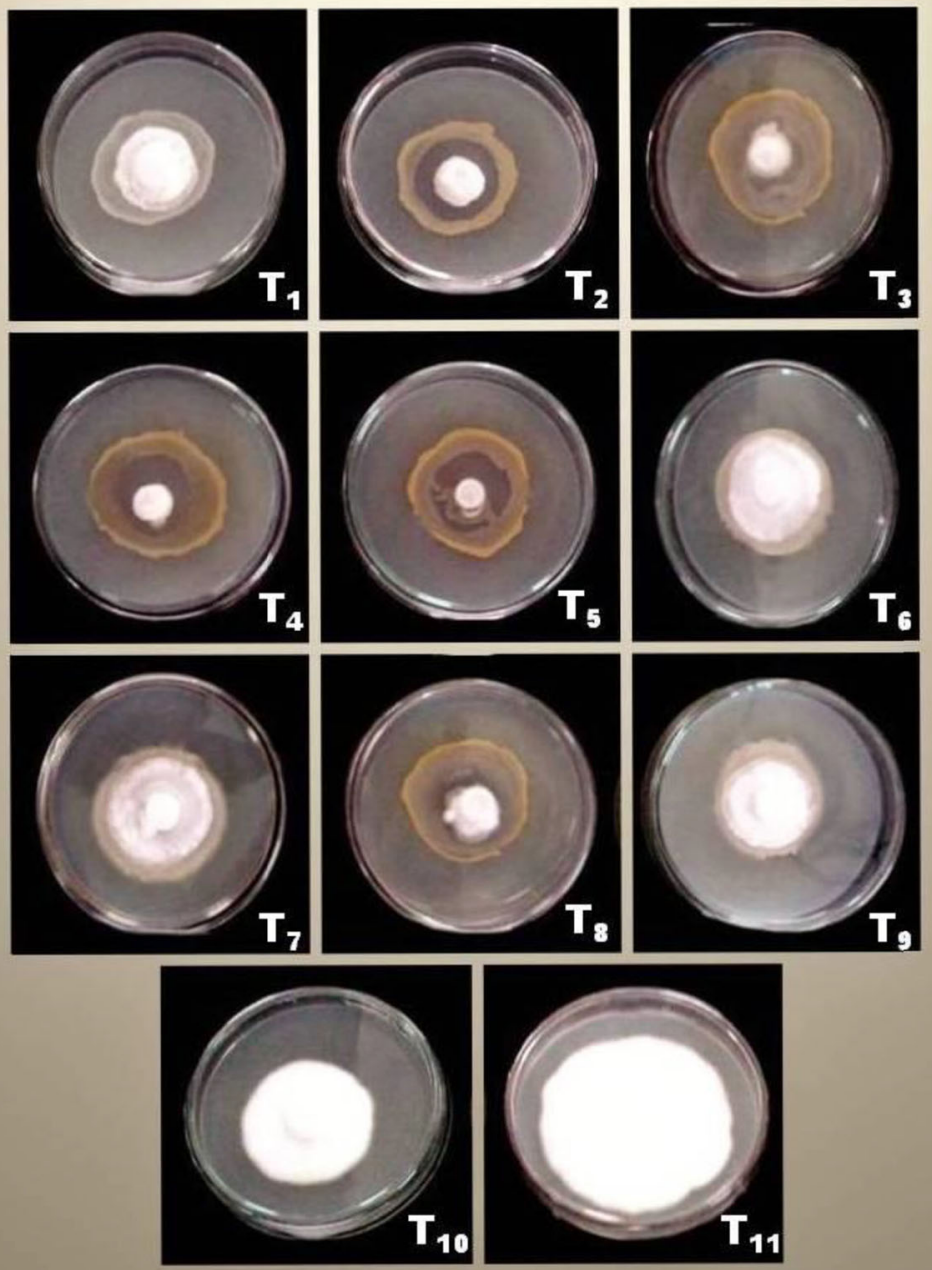

Fig. 1 Antagonism among 10 isolates of Pseudomonas fluorescens (Pf) and Fusarium oxysporum f. sp. cumini (Foc) at 6 days after inoculation in

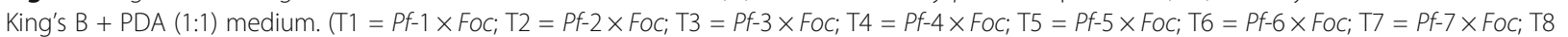
$=P f-8 \times$ Foc $; \mathrm{T} 9=P f-9 \times$ Foc $; \mathrm{T} 10=P f-10 \times$ Foc $;$ T11 $=$ Control - Foc $)$

mustard cake) and biological agent (Trichoderma harzianum, T. viride, $P$. fluorescens, and B. subtilis) reported that the maximum inhibition of Foc mycelial growth was under Pf treatment (Chawla and Gangopadhyay, 2009), which concurs with the findings of the current work. Kumar et al. (2016) tested the efficacy of different fungal and bacterial antagonists against wilt of cumin and found that $P f$ isolates were highly inhibitory to the pathogen under laboratory conditions. Moreover, several studies have found $P f$ to be an efficient bio-agent against $F$. oxysporum variants as pathogen of different crops including chickpea (Vidhyasekaran and Muthamilan, 1995), radish (De Boer et al., 1998), groundnut (Rini and Sulochana, 2008), banana (Mohammed et al., 2011), eggplant (Altinok et al., 2013), and tomato (Deshmukh et al., 2015).
Production of cell wall degrading enzymes by pathogen Foc during antagonism

The fungal pathogen produces lytic enzymes that degrade the host cell wall, while the presence of biological agent inhibits the production of these enzymes (Bishi and Vakharia, 2015). Therefore, the production of cell wall degrading enzymes (CWDEs) was conducted during antagonism in this study. Specific activity of cellulase (expressed as U.mg ${ }^{-1}$ protein) was significantly increased at control treatment T11 (25.98) (Foc alone), followed by the treatments T10 (18.62), T7 (18.03), T1 (15.17), T6 (13.65), T9 (12.73), T8 (11.55), and T2 (8.47) at 6 DAI (Fig. 3a), while decreased cellulase activity was observed at the treatments T5 (2.54), followed by T4 (3.51) and T3 (5.12). Furthermore, the lowest PG activity was 


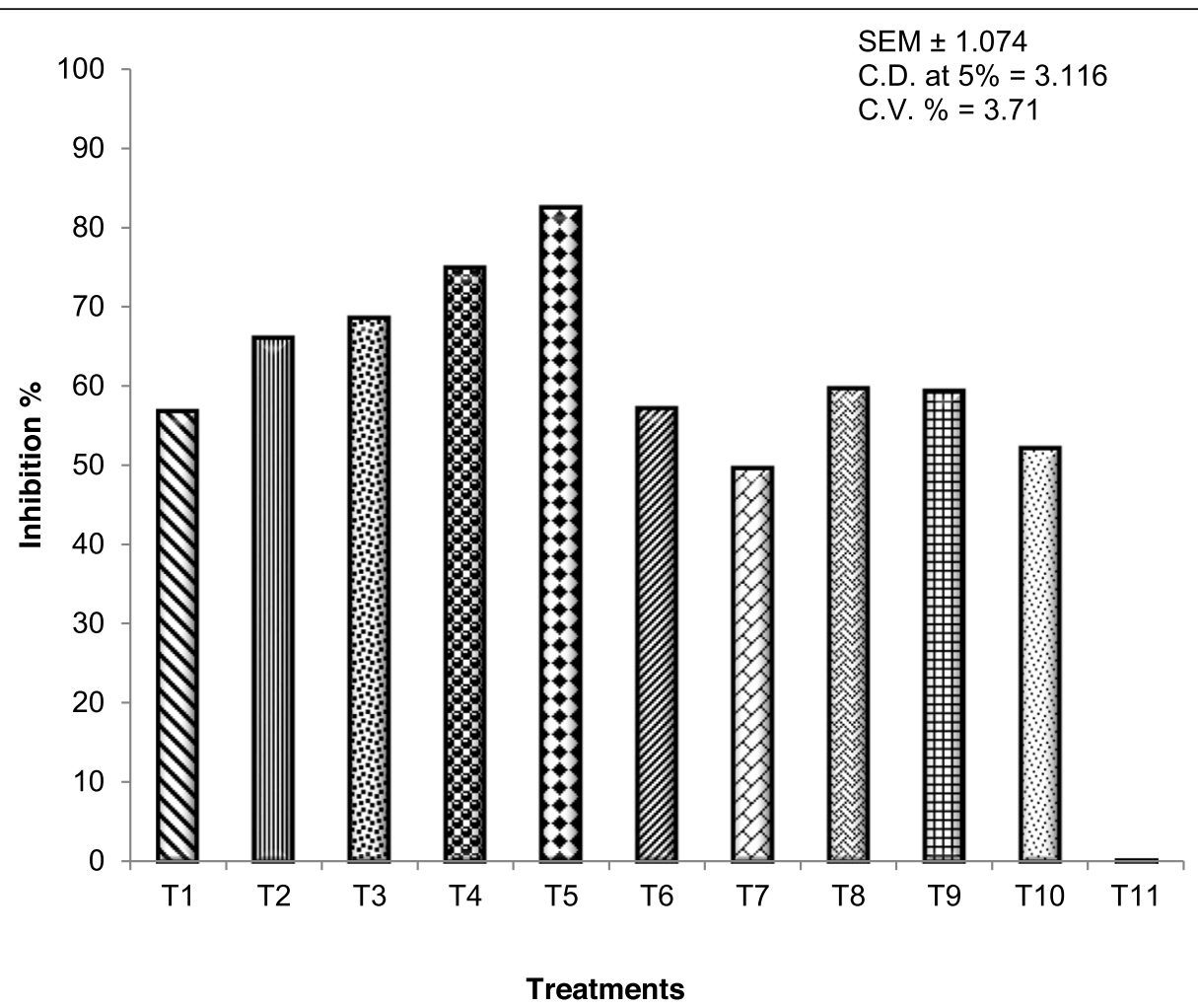

Fig. 2 Percent growth inhibition of Fusarium oxysporum f. sp. cumini (Foc) in in vitro antagonism with Pseudomonas fluorescens (Pf) isolates at 6

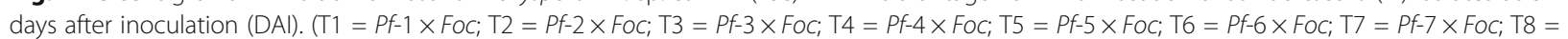
$P f-8 \times$ FoC; T9 $=$ Pf-9 $\times$ FoC; T10 $=$ Pf-10 $\times$ FoC; T11 = Control - FoC $)$

detected in treatment T5 (3.91), and the highest value of 24.68 was recorded at T10 among the treatments T110, while increased PG activity (35.22) was observed at treatment T11 (Fig. 3a). The cell wall degrading enzymatic activities decreased in the culture medium as the growth of Foc was inhibited during antagonism with $P f$ and vice versa. The reduction of these enzymatic activities in treatments T1-10 compared to control treatment T11 may indicate the capacity of respective Pf1-10 isolates to neutralize/suppress the CWDEs produced by Foc during its insertion/penetration mechanism.

The cell wall of pathogens that act as biological agent or host plants serves as the first physical barrier that confines the entry of most phytopathogens (Deshmukh et al., 2015). Thus, for the successful entry of the fungal hyphae and subsequent tissue colonization requires cell wall degradation by enzymatic processes. Most necrotrophic fungal pathogens produce CWDEs such as cellulase and PG to facilitate their entry into the host cells (van Kan, 2006). In response, the host plants and/or related $P f$ bio-agent produce enzymes such as chitinase, $\beta$ 1,3 glucanase, and protease (collectively referred as pathogenesis-related enzymes) to prevent the entry of the fungal pathogens. Treatment T5 showed a significant reduction of cellulase (89.83\%) and PG (88.89\%) enzyme production, demonstrating that the metabolites produced by isolate $P f-5$ were more effective than other $P f$ isolates used in this study. Correspondingly, Kishore et al. (2006) found that cell free culture filtrate of Pseudomonas spp. at 25\% dilutions inhibited the in vitro production of fungal CWDEs such as cellulase and PG, which are in agreement with the findings of this research where live cell cultures of $P f$ were tested. Production of such lytic enzymes is commonly found among antagonistic microorganisms (Adesina et al., 2007). Moreover, lytic enzymes produced by Pseudomonas solanacearum target virulence factors of $F$. oxysporum, thereby facilitating induced resistance to tomato plants against wilt disease (Toyoda et al., 1988).

\section{Production of pathogenesis related enzymes by bio-agent isolates $P f 1-10$}

In the present study, the activity of hydrolytic enzymes was carried out during antagonism of $P f$ isolates with Foc (Fig. 3b). The in vitro protease activity (recorded as

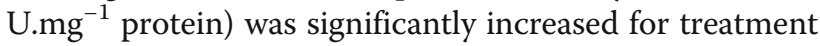
T5 (32.14), which was $\sim 11$ times higher than the control treatment T11 (2.94). While treatment T5 showed the maximum activity of chitinase (4.84) among the treatments (T1-10), the $\beta-1,3$ glucanase activity was 

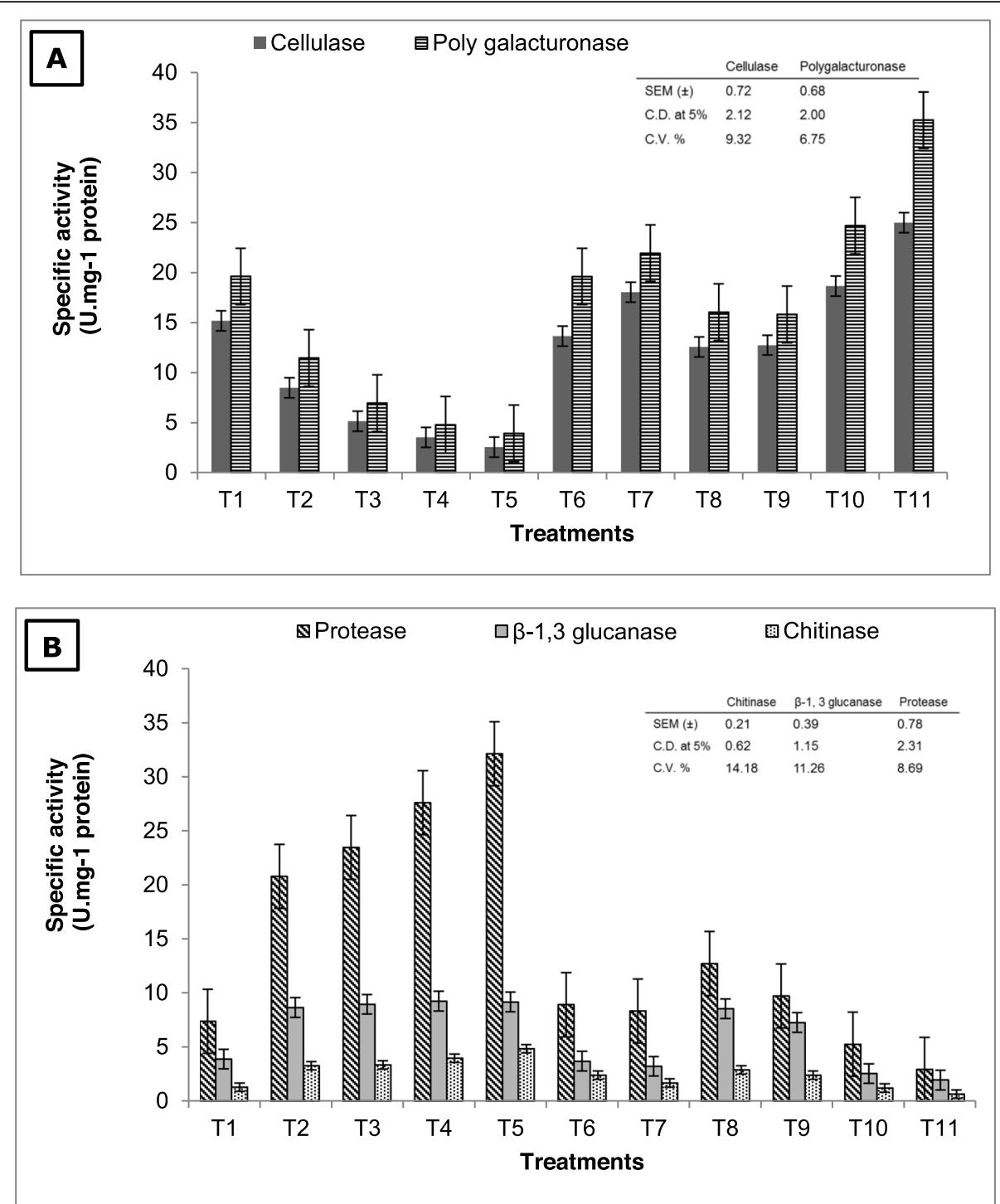

Fig. 3 In vitro production of a cell wall degrading enzymes and $\mathbf{b}$ pathogenesis-related enzymes in the culture medium at 6 days after inoculation (DAl). $(\mathrm{T} 1=P f-1 \times F O C ; \mathrm{T} 2=P f-2 \times F O C ; \mathrm{T} 3=P f-3 \times F O C ; \mathrm{T} 4=P f-4 \times F O C ; \mathrm{T} 5=P f-5 \times F O C ; \mathrm{T} 6=P f-6 \times F O C ; \mathrm{T} 7=P f-7 \times F O C ; \mathrm{T} 8=P f-8 \times F O C ;$ $\mathrm{T} 9=P f-9 \times$ Foc; $\mathrm{T} 10=P f-10 \times$ Foc; $\mathrm{T} 11=$ Control - Foc $)$

approximately similar for treatments $\mathrm{T} 4$ and $\mathrm{T} 5(9.25$ and 9.17), which was higher than other treatments (Fig. $3 \mathrm{~b})$. The isolate $P f-5$, which produced the highest protease and chitinase, but resulted in the lowest cellulase and polygalacturonase enzyme activity by Foc during antagonism experiments also showed the maximum in vitro growth inhibition of the fungus Foc. More interestingly, specific activity for $\beta-1,3$ glucanase for treatments $\mathrm{T} 2, \mathrm{~T} 3, \mathrm{~T} 4, \mathrm{~T} 5, \mathrm{~T} 8$, and $\mathrm{T} 9$ was at par (7.27 to 9.25), which denotes the equal potential of respective $P f$ isolates in $\beta-1,3$ glucanase production against Foc.

Plant resistance to pathogenic fungi involves multiple reaction pathways including the accumulation of hydrolytic enzymes such as protease, chitinase, and $\beta-1,3$ glucanase (Andersen et al., 2018). The highest activities of chitinase, protease, and possibly for $\beta-1,3$ glucanase in the antagonistic treatment $\mathrm{T} 5$ (i.e., interaction between $P f-5$ and pathogen $F o c$ ) than other treatments and untreated control further supported the finding of percent growth inhibition (Fig. 1) and the potentials of isolate Pf-5 to control Foc in vitro. The filamentous fungal cell wall also contains lipids and proteins (Riquelme et al., 2018). It was, therefore, expected that the antagonistic bacteria like P. fluorescens synthesized proteases, which may act on the cell wall of fungal pathogens. Also, P. fluorescence strain CV6 isolated from cucumber rhizosphere showed positive reactions for catalase, protease, and phosphatase and negative for the production of 
pectinase, lipase, and cellulase (Maleki et al., 2010) suggesting their potential as biocontrol agent. The biological control activity of $P$. fluorescens against certain soilborne phytopathogenic fungi and their potential to produce proteases that result in antagonistic activity against Macrophomina phaseolina, Rhizoctonia solani, Phytophthora nicotianae var. parasitica, Pythium spp., and Fusarium spp. by degrading cellulolytic enzymes produced by such pathogenic fungi has been previously reported (Ahmadzadeh et al., 2006).

Pseudomonas spp. were also known to produce chitinase in culture medium, and this production of chitinase was further increased when the growth medium was supplemented with chitin source or even with the fungal cell wall (Dev and Dawande, 2010). Saikia et al. (2005) reported that the production of lytic enzymes, i.e., chitinase and $\beta-1,3$ glucanase, by several PGPR strains of $P$. fluorescens is considered as a major antagonistic property of these strains. Another study revealed that $\beta-1,3$ glucanase produced by Pseudomonads decreased the incidence of diseases caused by Rhizoctonia solani, Sclerotium rolfsii, and Pythium ultimum by 85,48 , and $71 \%$, respectively (Fridlender et al., 1993). This further supports the findings of the present study that $P f$ isolates, more specifically $P f-5$, can be potentially used as a biological agent against Foc causing wilt disease in cumin.

\section{Correlation between percent growth inhibition of fungal pathogen and lytic enzymes}

The correlation study among specific lytic enzyme activity and percent growth inhibition showed a significant $(p=$ 0.01 ) but negative association (Table 1). This suggested that percentage growth inhibition decreased with increased concentration of cellulase and PG in the culture medium at 6 DAI. A significant positive correlation $(p=0.01)$ between percent growth inhibition of $F o c$ and the activity of chitinase, $\beta-1,3$ glucanase, and protease enzymes in the culture medium of antagonist established a relationship to inhibit the growth of fungal pathogen by increasing the levels of these lytic enzymes. However, CWDE cellulase and PG were negatively correlated with pathogenesis-related enzymes mainly chitinase and $\beta-1,3$ glucanase. While positive correlation was established among the protease and pathogenesis-related enzymes-chitinase and $\beta-1,3-$ glucanase (Table 1)-moreover, correlation analysis indicated a positive relation between percent growth inhibition and enzymes, i.e., chitinase, $\beta-1,3$ glucanase, and protease, produced by bio-agent $P f$, while a negative relation was observed for enzymes, viz., cellulase and polygalacturonase, produced by fungal pathogen Foc during antagonism. A phenomenon explaining the positive impact of the combination of two enzymes (chitinase and $\beta-1,3$ glucanase) on strong inhibition of fungal growth has been earlier reported (Saikia et al., 2005). Moreover, $P f$ isolates used for in vitro inhibition of $A$. niger, causal agent of groundnut collar rot, showed a similar correlation pattern during antagonism between P. fluorescens and A. niger (Deshmukh et al., 2015).

The damage caused by $F$. oxysporum f. sp. cumini is of economic importance for cumin growing regions of the world. Hence, integrated pest management strategies are in high demand to control this devastating fungus, especially in an eco-friendly and inexpensive way. Several pathogens as biocontrol agents have previously been reported to fight against cumin wilt. However, the efficacy of these pathogens as bio-agent varies depending on the fungal variant, region, plant host, and agro-climatic conditions.

\section{Conclusion}

Pseudomonas fluorescens (Pf) has been widely used as a biocontrol agent against many fungal pathogens. Among the tested isolates, $P f-5$ was the most suitable candidate as it exhibited the capacity to inhibit maximum growth of fungal pathogen. The findings are strongly supported by bio-chemical analyses during the antagonism $(P f \times F o c)$ experimentation. This study may enhance the existing knowledge of $P f \times F o c$ interactions and assist in identifying the potential isolate(s) for future use as a biocontrol agent against wilt disease of cumin. In future, it would be of interest to further investigate the potential of $P f-5$ isolate under controlled and/or field conditions as a biocontrol agent against cumin wilt.

Table 1 Correlation matrix between growth inhibitions of Fusarium oxysporum f. sp. cumini (Foc) and production of lytic enzymes during in vitro antagonism with Pseudomonas fluorescens (Pf) isolates in the culture medium at 6 days after inoculation (DAl)

\begin{tabular}{|c|c|c|c|c|c|c|}
\hline & $\%$ Growth inhibition & Cellulase & Poly galacturonase & Chitinase & $\beta-1,3$ glucanase & Protease \\
\hline$\%$ Growth inhibition & 1.000 & & & & & \\
\hline Cellulase & $-0.999^{* *}$ & 1.000 & & & & \\
\hline Poly galacturonase & $-0.993^{* *}$ & $0.994^{* *}$ & 1.000 & & & \\
\hline Chitinase & $0.991^{* *}$ & $-0.992^{* *}$ & $-0.998^{* *}$ & 1.000 & & \\
\hline$\beta-1,3$ glucanase & $0.644^{*}$ & $-0.633^{*}$ & $-0.691^{*}$ & $0.725^{* *}$ & 1.000 & \\
\hline Protease & $0.703^{* *}$ & $-0.689^{*}$ & $-0.734^{* *}$ & $0.768^{* *}$ & $0.987^{*}$ & 1.000 \\
\hline
\end{tabular}

Critical value $(p=0.05)=0.562 ;(p=0.01)=0.695^{* *}$ 


\section{Abbreviations}

Foc: Fusarium oxysporum f. sp. cumini; Pf: Pseudomonas fluorescens; PDA: Potato-Dextrose Agar; DAl: Days after inoculation; CMC: Carboxy methyl cellulose; CWDEs: Cell wall degrading enzymes; PG: Polygalacturonase

\section{Acknowledgements}

The authors would like to thank Dr. U. K. Kandoliya, Asst. Professor, Dept. of Biochemistry, Junagadh Agricultural University, India, for providing the Pseudomonas fluorescens isolates used in the present study. The authors also extend their appreciation to the Head of Dept. Dr. B. A. Golakiya for his support during this research work.

\section{Authors' contributions}

RR designed and performed all the experimental work under supervision of DNV and advised by DSR. All authors have contributed to the manuscript preparation, read, and approved the final manuscript.

\section{Funding}

This study was financially supported by the department of biochemistry at the university.

\section{Availability of data and materials}

All data and material used can be availed from corresponding author upon request.

\section{Ethics approval and consent to participate}

Not applicable.

\section{Consent for publication}

Not applicable.

\section{Competing interests}

Authors declare that they have no competing interest.

Received: 4 January 2020 Accepted: 29 April 2020

Published online: 12 May 2020

\section{References}

Adesina MF, Lembke A, Costa R, Speksnijder A, Smalla K (2007) Screening of bacterial isolates from various European soils for in vitro antagonistic activity towards Rhizoctonia solani and Fusarium oxysporum: site-dependent composition and diversity revealed. Soil Biol Biochem 39:2818-2828

Ahmadzadeh M, Afsharmanesh H, Javan-Nikkhah M, Sharifi-Tehrani A (2006) Identification of some molecular traits in fluorescent pseudomonads with antifungal activity. Iran J Biotechnol 4:245-253

Altinok HH, Dikilitas M, Yildiz HN (2013) Potential of Pseudomonas and Bacillus isolates as biocontrol agents against fusarium wilt of eggplant. Biotechnol Biotechnol Equip 27:3952-3958

Andersen EJ, Ali S, Byamukama E, Yen Y, Nepal MP (2018) Disease resistance mechanisms in plants. Genes 9(7):339-368

Bhatnagar K, Tak S, Sharma R, Majumdar V, Meena R (2013) Management of cumin wilt caused by Fusarium oxysporum f. sp. cumini through chemical and biological agents. Indian Phytopathol 66:101-102

Bishi S, Vakharia D (2015) Secondary metabolites and lytic enzymes produced by fluorescent pseudomonads determine in-vitro antagonistic potential against Sclerotium rolfsii in groundnut (Arachis hypogaea L.). J Pure Appl Microbiol 9: 3283-3293

Booth C (1971) The genus Fusarium. Commonwealth mycological institute, Kew, Surrey (England) pp-237.

Chawla N, Gangopadhyay S (2009) Integration of organic amendments and bioagents in suppressing cumin wilt caused by Fusarium oxysporum f. sp. cumini. Indian Phytopathol 62:209-216

Chawla N, Gangopadhyay S, Dhaka B (2012) Eco-friendly approach for suppressing Fusarium wilt of cumin. Plant Dis Res (Ludhiana) 27:127-133

De Boer M, Van Der Sluis I, Van Loon L, Bakker P (1998) In-vitro compatibility between fluorescent Pseudomonas spp. strains can increase effectivity of Fusarium wilt control by combinations of these strains. IOBC WPRS Bull 21: $257-262$

Deshmukh S, Bishi S, Vakharia D (2015) Pseudomonas fluorescens modulate in-vitro lytic enzyme production and inhibit the growth of collar rot pathogen
(Aspergillus niger) in groundnut (Arachis hypogaea L.). J Pure Appl Microbiol 9 1531-1538

Dev N, Dawande A (2010) Biocontrol of soil borne plant pathogen Rhiozoctonia solani using Trichoderma spp. and Pseudomonas fluorescens. Asiatic J Biotech Res 1:39-44

Fatima Z, Saleemi M, Zia M, Sultan T, Aslam M, Rehman R, Chaudhary M (2009) Antifungal activity of plant growth-promoting rhizobacteria isolates against Rhizoctonia solani in wheat. Afr J Biotechnol 8:219-225

Fridlender M, Inbar J, Chet I (1993) Biological control of soilborne plant pathogens by a $\beta-1,3$ glucanase-producing Pseudomonas cepacia. Soil Biol Biochem 25:1211-1221

Iftikhar Y, Sajid A, Shakeel Q, Ahmad Z, Haq ZU (2020) Biological antagonism: a safe and sustainable way to manage plant diseases. In Plant disease management strategies for sustainable agriculture through traditional and modern approaches Springer:83-109

Israel S, Mawar R, Lodha S (2005) Soil solarisation, amendments and bio-control agents for the control of Macrophomina phaseolina and Fusarium oxysporum f. sp. cumini in aridisols. Ann Appl Biol 146:481-491

Kandoliya U, Vakharia D (2013) Antagonistic effect of Pseudomonas fluorescens against Fusarium oxysporum $\mathrm{f}$. sp. ciceri causing wilt in chickpea. Legum Res 36:569-575

Kishore G, Pande S, Podile A (2006) Pseudomonas aeruginosa GSE 18 inhibits the cell wall degrading enzymes of Aspergillus niger and activates defencerelated enzymes of groundnut in control of collar rot disease. Australas Plant Pathol 35:259-263

Kumar S, Gangopadhyay S, Godara S (2016) Antagonistic potentiality of bioagents against wilt of cumin (Cuminum cyminum) caused by Fusarium oxysporum f. sp. cumini. Indian J Agric Sci 86(10):1350-1356

Lee YP, Takahashi T (1966) An improved colorimetric determination of amino acids with the use of ninhydrin. Anal Biochem 14:71-77

Lodha S, Mawar R (2014) Cumin wilt management: a review. J Spice Aromat Crop 23:145-155

Maleki M, Mostafaee S, Mokhtarnejad L, Farzaneh M (2010) Characterization of Pseudomonas fluorescens' strain CV6 isolated from cucumber rhizosphere in Varamin as a potential biocontrol agent. Aust J Crop Sci 4(9):676-683

Malik CP, Singh MB (1980) Plant enzymology and histo-enzymology. Kalyani Publishers, New Delhi, India, p-9.

Mohammed AM, Al-Ani LK, Bekbayeva L, Salleh B (2011) Biological control of Fusarium oxysporum f. sp. cubense by Pseudomonas fluorescens and BABA in vitro. World Appl Sci J 15:189-191

Özer G, Bayraktar H (2015) Determination of fungal pathogens associated with Cuminum cyminum in Turkey. Plant Prot Sci 51:74-79

Petit AN, Fontaine F, Vatsa P, Clément C, Vaillant-Gaveau N (2012) Fungicide impacts on photosynthesis in crop plants. Photosynth Res 111:315-326

Raymaekers K, Ponet L, Holtappels D, Berckmans B, Cammue BPA (2020) Screening for novel biocontrol agents applicable in plant disease management - a review. Biol Control 104240

Reissig JL, Strominger JL, Leloir LF (1955) A modified colorimetric method for the estimation of N-acetylamino sugars. J Biol Chem 217:959-966

Rini C, Sulochana K (2008) Usefulness of Trichoderma and Pseudomonas against Rhizoctonia solani and Fusarium oxysporum infecting tomato. J Trop Agric 45:21-28

Riquelme M, Aguirre J, Bartnicki-Garć́a S, Braus GH, Feldbrügge M, Fleig U, Hansberg W, Herrera-Estrella A, Kämper J, Kück U (2018) Fungal morphogenesis, from the polarized growth of hyphae to complex reproduction and infection structures. Microbiol Mol Biol Rev 82:e00068-e00017

Sadasivam S, Manickam A (1992) Phenolics. Biochemical Methods for Agricultural Sciences, Wiley eastern limited:187-188

Saikia R, Singh B, Kumar R, Arora D (2005) Detection of pathogenesis-related proteinschitinase and $\beta-1,3$ glucanase in induced chickpea. Curr Sci 89(4):659-663

Sivan A, Chet I (1989) Degradation of fungal cell walls by lytic enzymes of Trichoderma harzianum. Microbiology 135:675-682

Toyoda H, Hashimoto H, Utsumi R, Kobayashi H, Ouchi S (1988) Detoxification of fusaric acid by a fusaric acid-resistant mutant of Pseudomonas solanacearum and its application to biological control of Fusarium wilt of tomato. Phytopathol (USA) 78:1307-1311

Van Kan JAL (2006) Licensed to kill: the lifestyle of a necrotrophic plant pathogen. Trends Plant Sci 11:247-253

Vidhyasekaran P, Muthamilan M (1995) Development of formulations of Pseudomonas fluorescens for control of chickpea wilt. Plant Disease (USA) 79:782-786

\section{Publisher's Note}

Springer Nature remains neutral with regard to jurisdictional claims in published maps and institutional affiliations. 